\title{
Atypical, high-diversity assemblages of foraminifera in a mangrove estuary in northern Brazil
}

\author{
Nisan Sariaslan and Martin R. Langer \\ Institute für Geowissenschaften, Paläontologie, Universität Bonn, Bonn 53115, Germany \\ Correspondence: Martin R. Langer (martin.langer@uni-bonn.de) \\ Received: 1 March 2021 - Discussion started: 29 March 2021 \\ Revised: 31 May 2021 - Accepted: 1 June 2021 - Published: 7 July 2021
}

\begin{abstract}
Mangrove forests are extremely productive ecosystems, are sources and sinks of organic carbon, and provide essential services both to the marine environment and people. We have studied the composition and species richness of modern benthic foraminiferal assemblages from mangrove swamps along the Mamanguape River in Paraíba, northern Brazil. Sampling points for foraminifera were selected to acquire information on the composition of foraminiferal assemblages from dense mangrove stands collected along a river transect. Almost 100 species of benthic foraminifera were identified within the shallow mangrove habitats. The large number of identified mangrove taxa is the highest recorded so far for true mangrove habitats. The high species richness rivals shallow-water assemblages recorded from nearby offshore and reef environments and indicates that a particularly large number of species is capable of growing and flourishing under multiple stressor conditions. Numerical analysis of the faunal assemblages shows that specific taxa, which were previously known to be uncommon in mangrove environments, are abundant in the Mamanguape River estuary. The atypical foraminiferal fauna found in the Mamanguape River estuary resembles shallowwater offshore assemblages, is characterized by high percent abundances of perforate and miliolid taxa, and contains only very few of the otherwise typical and numerically abundant agglutinated mangrove taxa. The unusual structure of the assemblages recorded provides insight into what combination of environmental variables controls their composition and novel perspectives to reconstruct past mangrove environments. Distribution, diversity, and species-specific analysis will provide guidance on the use of Brazilian mangrove foraminifera as indicators for the strength of tidal activity, pollution, and anoxia in coastal waters and sea-level reconstructions.
\end{abstract}

\section{Introduction}

Mangrove ecosystems around the world play an important role in protecting biodiversity, preserving shorelines, and regulating carbon cycling. They respond actively to coastal processes and sediment input and are considered one of the best geological indicators for the detection of modifications in coastal zone dynamics (Cunha-Lignon et al., 2009). Brazil is home to approximately $15 \%$ of the world's total mangal forest areas but the release of effluents and untreated wastewater pose threats to ecosystems and marine biota. Nearly $6700 \mathrm{~km}(90 \%)$ of Brazil's $7400 \mathrm{~km}$ of coastline hosts mangrove forests. The Mamanguape River estuary is the second largest estuary in the northeastern state of Paraíba (Brazil) covering a mangrove swamp area of more than $57 \mathrm{~km}^{2}(\mathrm{Bez}-$ erra et al., 2012).

Mangrove ecosystems are subject to a suite of disturbances that vary in their intrinsic nature (e.g., geological, physical, chemical, and biological) in time and space. Inhabiting the interface between land and sea at low latitudes, these ecosystems occupy a harsh environment and are subject to daily tidal, temperature, and salinity variations as well as varying degrees of anoxia. Mangrove forests and their inhabitants are therefore rather robust and highly tolerant to life in their saline environments within warm, subtropical, and tropical seascapes (Alongi, 2008). In addition to the natural fluctuations, anthropogenic activities also affect these ecosystems. The estuaries of the northeastern ecoregion are among the most affected by the human occupation processes in Brazil and need actions that guide an integrated management to maintain ecosystem sustainability. Cities close to the Mamanguape River estuary have a total of nearly 40000 inhabitants (Instituto Brasileiro de Geografia e Estatistica, 2019) and extensive sugarcane and shrimp aquaculture fields place 
environmental pressure on the mangrove ecosystem. The synergistic effects of multiple stressors may cause broadscale changes in estuarine and coastal ecosystems impacting the abundance, species richness, and distribution of functionally important taxa. The interactions of multiple stressors are likely to increase as climate change and anthropogenic pressures will alter the delivery of freshwater and associated nutrients and pollutants to estuarine and coastal ecosystems (Scavia et al., 2002; Paerl et al., 2006; Gillanders et al., 2011; Schiedek et al., 2008). Understanding the response of benthic communities to key stressors is vital for managing mangrove environments and the first step towards setting ecologically relevant limits.

Foraminifera in tropical mangrove environments of South America and the islands nearby have been studied since the late 1940s in Trinidad (Cushman and Brönnimann, 1948a, b; Wilson et al., 2008), the Gulf of Paria (Todd and Brönnimann, 1957), Bahia (Zaninetti et al., 1979; Hiltermann et al., 1981; Eichler et al., 2015; Laut et al., 2016), Rio de Janeiro (Brönnimann et al., 1981; Debenay et al., 2001; Barbosa et al., 2005; Laut et al., 2016; Martins et al., 2016; Gasparini and Vilela, 2017; Belart et al., 2019), Colombia (Boltovskoy and Hincapié de Martínez, 1983), Puerto Rico (Culver, 1990), French Guiana (Debenay et al., 2002, 2004), Santa Catarina (Laut et al., 2016), Sao Paulo (Eichler et al., 2007; Passos et al., 2017; Eichler et al., 2019), and Rio Grande do Sul (Laut et al., 2016; Damasio et al., 2020; Semensatto et al., 2009). Most foraminifera assemblages studied from true mangrove settings were previously reported to be dominated by agglutinated species in a low-diversity ensemble (e.g., Boltovskoy, 1984; Culver, 1990; Debenay, 1990; Murray, 1991; Brönnimann et al., 1992 and references therein). However, we were persuaded to perform an in-depth investigation of our samples upon observing highly diverse and calcareous-dominated assemblages in our preliminary results. The objectives of the present study were (i) to provide detailed documentation on the structure and species richness of foraminiferal assemblages in mangroves of the Mamanguape River estuary of northern Brazil, (ii) to understand the driving forces contributing to the unusual composition and high diversity of these assemblages, and (iii) to discuss implications for interpreting the fossil record of foraminiferal mangrove assemblages.

\section{Regional setting}

The Mamanguape River estuary system is located on the coast of Paraíba State in northeastern Brazil and bound by latitudes $6^{\circ} 43^{\prime} 02^{\prime \prime} \mathrm{S}$ to $6^{\circ} 51^{\prime} 54^{\prime \prime} \mathrm{S}$ and longitudes $35^{\circ} 07^{\prime} 46^{\prime \prime} \mathrm{W}$ to $34^{\circ} 54^{\prime} 04^{\prime \prime} \mathrm{W}$ (Fig. 1). It is situated in an incised river valley, formed along a graben structure and oriented perpendicular to the coastline (Bezerra et al., 2001). The Mamanguape River estuary belongs to the Northeastern Marine Ecoregion (NEME; Spalding et al., 2007), covers an area of $\sim 658 \mathrm{~km}^{2}$, and is characterized by different rainfall regimes with varying rates of precipitation and duration during the wet and dry periods. As a result, a pronounced environmental variability among NEME estuaries is observed, where the highest reported $\mathrm{pH}$ (9.5) was recorded in the Mamanguape River (see Table 3.1 in Rafaela et al., 2018).

Radiocarbon dates collected from core sample material provide evidence that the inundation of the estuary occurred over the last 6000 years and more abruptly within the last 1000 years (Alvez, 2015). The dissolved oxygen levels in the estuary are controlled by a balance between the deoxygenation caused by the intense vegetation and tidal cycles and the oxygenation brought by bioturbating organisms. It is likely that hypoxia is a common condition of intertidal Mamanguape mangrove environments due to the mineralization of a large amount of organic matter produced by mangrove trees, which is responsible for a high consumption of oxygen by bacteria (Alongi et al., 2004) but also due to the exchange of porewater between sediments and the water column, known as "tidal pumping" (Li et al., 2009; Gleeson et al., 2013; Call et al., 2015; Leopold et al., 2017). According to Nordi et al. (2009), the tidal cycle is semi-diurnal on the northeastern coast of Brazil, producing two floods and two ebbs per day with a tidal range of approximately $2.8 \mathrm{~m}$ (Paludo and Klonowski, 1999). The estuary is heavily bioturbated by macrofaunal organisms such as oligochaetes, polychaetes, gastropods, bivalves, and shipworms. In addition, crabs and fish are diverse and abundant and are part of the vibrant ecosystem found in the estuary (Leonel et al., 2002; Nascimento et al., 2016; Van der Linden et al., 2017). Thus, sediments of the Mamanguape River estuary are heterogenous in terms of their oxygen content; they rapidly become anoxic below the sediment surface, but bioturbation results in localized oxygenation of sediments around macrofaunal burrows (see also Langer et al., 1990).

\section{Material and methods}

Sediment samples were collected from the top $2 \mathrm{~cm}$ in September 2006 along the Mamanguape River estuary (Fig. 1). This time of the year falls within the dry season (August to November; Debenay et al., 2004) and the year 2006 is considered a "very dry" year and the driest between 2002 and 2006 (Santos et al., 2015). The sampling sites selected are located along the main and tributary mangrove channels and are scattered along a $2 \mathrm{~km}$ traverse upstream (Fig. 2). Samples were taken during a post-conference field trip at FORAMS 2006, the largest international symposium on foraminifera promoting the exchange of foraminiferal material under permission of the national science community. Sampling was conducted within dense mangrove stands and with distance from the channels $(>10 \mathrm{~m})$ to avoid potentially allochthonous species transported by currents along the channel. Sampling points are located directly around the 


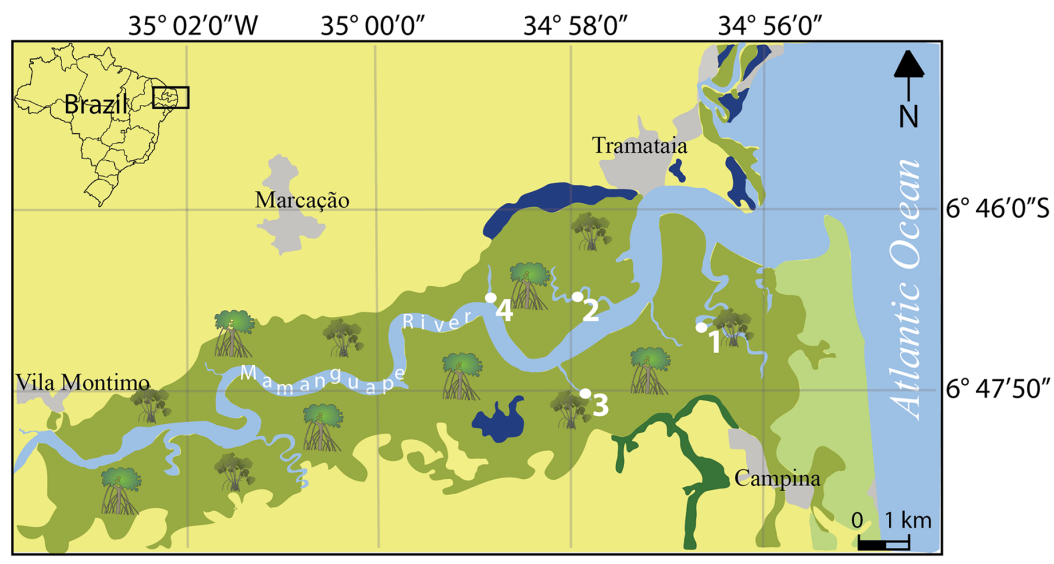

Land use

Agriculture

Aquaculture

Rain forest

Restinga

Urban areas

Figure 1. Map of the Mamanguape River estuary with sample site locations (modified from Dolbeth et al., 2016).

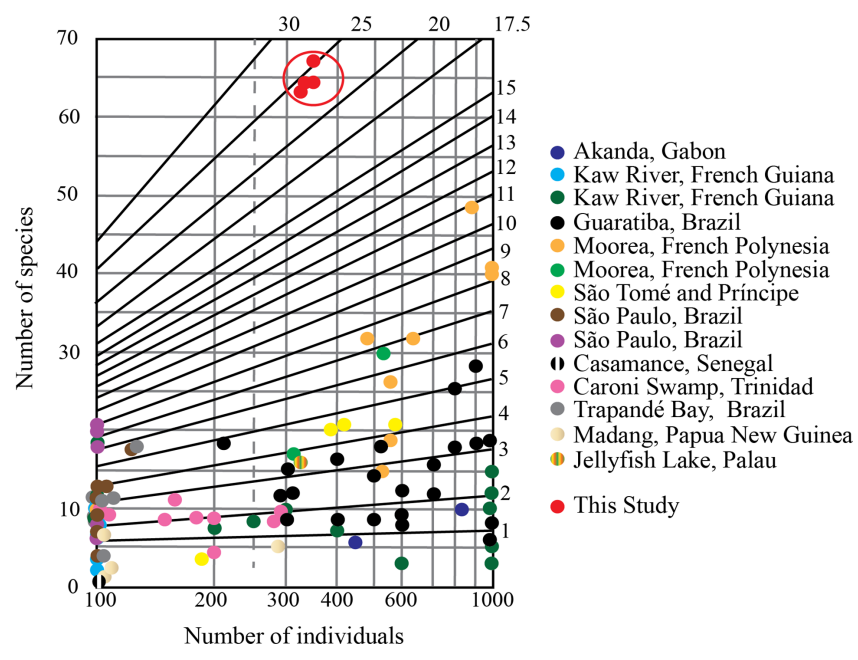

Figure 2. Fisher $\alpha$ diversity index graph for foraminiferal samples from the Mamanguape River estuary in comparison to total assemblages reported in previous mangrove studies (data from Brönnimann et al., 1981 (Guaratiba, Brazil); Rouvillois, 1982 (Casamance, Senegal); Lipps and Langer, 1999 (Jellyfish Lake, Palau); Debenay et al., 2002, 2004 (Kaw River, French Guiana); Langer and Lipps, 2003 (Madang, Papua New Guinea); Langer and Lipps, 2006 (Moorea, French Polynesia); Wilson et al., 2008 (Trinidad); Fajemila et al., 2015 (Moorea, French Polynesia); Langer et al., 2016 (Akanda, Gabon); Fajemila and Langer, 2017 (Sao Tome and Príncipe); Eichler, 2018 (Sao Paulo, Brazil); and Semensatto et al., 2009 (Trapandé Bay, Brazil)).

roots within the mangrove trees and the sediments collected are composed of organic-rich mud and silt.

The samples were washed over $63 \mu \mathrm{m}$ sieves and dried at room temperature; a total of $\sim 1352$ foraminifera specimens (death assemblage) were picked from these samples
(Table 1). To standardize the number of individuals recorded in individual samples and to avoid potential pitfalls (Patterson and Fishbein, 1989; Murray, 2006), picking was limited to a weight of $0.05 \mathrm{~g}$ of washed and dried sediment. All specimens were identified to species level, illustrated by scanning electron microscopy (SEM), and arranged into plates using Adobe Illustrator CS5 (Figs. 3-9). The total number of individuals was then counted for each species (Table 1) and their abundance and distribution patterns were analyzed.

As a measure of diversity, species richness was determined for each sample and is illustrated by the Fisher $\alpha$ diversity index (Fig. 2, Table 2; Fisher et al., 1943; Murray, 1973). To this end, the total number of individuals has been plotted against the total number of species via the PAST software (Hammer et al., 2001) to compare the foraminiferal assemblage diversity and species richness with respect to the sampled locations. In addition, the Shannon diversity index $(H)$ was calculated to characterize species diversity in foraminiferal communities. The Shannon diversity index accounts for both abundance and evenness of the species present. The proportion of species $i$ relative to the total number of species $\left(p_{i}\right)$ is calculated and then multiplied by the natural $\operatorname{logarithm}$ of this proportion $\left(\ln p_{i}\right)$. The resulting product is summed across species and multiplied by -1 :

$H=-\sum_{J=1}^{s} p_{j} \ln \left(p_{j}\right)$

Species richness and Fisher $\alpha$ diversity values were then compared to other mangrove studies from around the world to place our study in perspective. Lastly, the foraminiferal fauna was documented on plates (Figs. 3-9). All specimens are deposited in the micropaleontological collection at the Institute of Geosciences, University of Bonn (Germany). 
Table 1. Alphabetical list, abundance of all species of foraminifera identified, and total abundance of specimens, genera, and species in the samples from the Mamanguape River estuary.

\begin{tabular}{|c|c|c|c|c|}
\hline Species & Sample 1 & Sample 2 & Sample 3 & Sample 4 \\
\hline Abditodentrix rhomboidalis & 2 & 2 & 2 & 4 \\
\hline Adelosina milletti & 3 & 4 & 2 & 3 \\
\hline Ammonia advena & 2 & 3 & 3 & 1 \\
\hline Ammonia veneta & 23 & 11 & 11 & 20 \\
\hline Amphistegina lessonii & 1 & 1 & & \\
\hline Amphistegina radiata & 1 & & & \\
\hline Angulogerina cf. A. occidentalis & 2 & 7 & 5 & 7 \\
\hline Anomalinulla glabrata & 1 & 2 & & \\
\hline Anomalinulla sp. 1 & 25 & 17 & 18 & 17 \\
\hline Arenoparella mexicana & & & & 1 \\
\hline Articulina alticostata & & & & 1 \\
\hline Astrononion gallowayi & 2 & 1 & & \\
\hline Bigenerina sp. 1 & 1 & 2 & 2 & 1 \\
\hline Bolivina brevior & 2 & & 1 & \\
\hline Bolivina densipunctata & 4 & 3 & & \\
\hline Bolivina ordinaria & 9 & 9 & 2 & 2 \\
\hline Bolivina striatula & 4 & 5 & 1 & 7 \\
\hline Bolivina sp. 1 & & 2 & & \\
\hline Bolivina variabilis & 1 & 1 & & 7 \\
\hline Bolivina cf. B. variabilis & 6 & 6 & 13 & 10 \\
\hline Buliminella elegantissima & 1 & & 1 & \\
\hline Cassidelina sp. 1 & 2 & 2 & 1 & 2 \\
\hline Cornuspira involvens & 5 & 5 & 3 & 1 \\
\hline Cornuspira planorbis & & & 1 & 1 \\
\hline Cribroelphidium mirum & 2 & 6 & 12 & 5 \\
\hline Cushmanina bricei & & & 1 & 2 \\
\hline Discorbis williamsoni & 1 & & & 1 \\
\hline Discorbitina pustulata & & 1 & 1 & 2 \\
\hline Edentostomina sp. 1 & 2 & 3 & 2 & 3 \\
\hline Elphidium sagrum & & 2 & 3 & 3 \\
\hline Elongobula parallela & 4 & 10 & 9 & 7 \\
\hline Eoponidella pulchella & 4 & 1 & & \\
\hline Fischerina sp. 1 & 1 & & & \\
\hline Fissurina sp. 2 & 2 & 1 & 2 & 1 \\
\hline Fissurina bispinata & & & 1 & \\
\hline Fissurina colomboensis & 1 & 2 & 2 & 3 \\
\hline Fissurina semimarginata & & 2 & 1 & 2 \\
\hline Fissurina ? sp. 1 & 1 & & & \\
\hline Glabratella carinata & 2 & 4 & 2 & 3 \\
\hline Glabratella mirabilis & 2 & 1 & 1 & 2 \\
\hline Globocassidulina crassa & 2 & 2 & 5 & 4 \\
\hline Globocassidulina rossensis & 2 & 4 & 3 & \\
\hline Hauerina atlantica & & & & 1 \\
\hline Inaequalina sp. 1 & & & & 1 \\
\hline Laevipeneroplis bradyi & & & & 1 \\
\hline Lagena tenuis & & & & 1 \\
\hline Loxostomina costulata & 5 & 1 & 1 & \\
\hline Miliolinella webbiana & & 1 & 2 & 3 \\
\hline Miliolinella sp. 1 & 1 & & 1 & 1 \\
\hline Mychostomina revertens & & & & 1 \\
\hline Neoconorbina radiatogranulata & & 1 & 1 & 2 \\
\hline Neoconorbina sp. 1 & 3 & 3 & 4 & 4 \\
\hline Neoconorbina terquemi & & 5 & 1 & 1 \\
\hline Nonionoides grateloupii & 8 & 5 & 2 & 4 \\
\hline
\end{tabular}


Table 1. Continued.

\begin{tabular}{|c|c|c|c|c|}
\hline Species & Sample 1 & Sample 2 & Sample 3 & Sample 4 \\
\hline Orbitina carinata & 12 & 25 & 30 & 22 \\
\hline Pararotalia cananeiaensis & 81 & 76 & 75 & 71 \\
\hline Procerolagena oceanica & & & & 1 \\
\hline Pseudolachlanella eburnea & 1 & 2 & 2 & 3 \\
\hline Pseudolachlanella bermudezi & 9 & 6 & 6 & 12 \\
\hline Pseudotriloculina sp. 1 & 4 & 2 & 3 & 2 \\
\hline Pseudotriloculina sp. 2 & 2 & 2 & 1 & 2 \\
\hline Pseudotriloculina sp. 3 & 2 & 1 & 2 & 3 \\
\hline Quinqueloculina cf. Q. bosciana & 5 & 5 & 2 & 3 \\
\hline Quinqueloculina cf. Q. carinatastriata & 3 & 3 & 3 & 3 \\
\hline Quinqueloculina cuvierina & 10 & 8 & 16 & 15 \\
\hline Quinqueloculina moynensis & 19 & 22 & 15 & 17 \\
\hline Quinqueloculina poeyana & 1 & & & \\
\hline Quinqueloculina cf. Q. rebeccae & 1 & 1 & & \\
\hline Quinqueloculina samoaensis & 3 & 5 & 4 & 4 \\
\hline Quinqueloculina tantabiddyensis & 1 & 1 & & \\
\hline Quinqueloculina sp. 1 & 2 & & 1 & 2 \\
\hline Quinqueloculina quinquecarinata & 1 & & 1 & 1 \\
\hline Quinqueloculina sp. 2 & & & 3 & 2 \\
\hline Quinqueloculina sp.3 & 2 & 2 & 3 & 3 \\
\hline Quinqueloculina sp. 4 & & 1 & & \\
\hline Quinqueloculina cf. Q. compta & & 1 & 1 & 2 \\
\hline Quinqueloculina cf. Q. zhengi & 1 & & & \\
\hline Rosalina sp. 1 & & 2 & 2 & 1 \\
\hline Rosalina sp. 2 & 15 & 14 & 8 & 11 \\
\hline Rosalina bradyi & & 7 & & 1 \\
\hline Rotaliammina trumbulli & 2 & & 1 & \\
\hline Rotorbis auberii & 4 & 5 & & 3 \\
\hline Sagrina pulchella & & 1 & 3 & 3 \\
\hline Sigmoilinita costata & 2 & & 2 & 1 \\
\hline Sigmavirgulina tortuosa & 1 & 3 & 6 & 2 \\
\hline Svratkina acuta & 2 & 1 & 1 & 2 \\
\hline Siphonina reticulata & 4 & 3 & 4 & 5 \\
\hline Spirillina grosseperforata & & & 1 & 1 \\
\hline Textularia sp. 1 & & 1 & 2 & 1 \\
\hline Textularia sp. 2 & & 2 & 1 & 1 \\
\hline Textularia cf. T. semialata & & 1 & & \\
\hline Trochammina inflata & 1 & & 1 & \\
\hline Wiesnerella auriculata & 4 & 5 & 5 & \\
\hline Total number of specimens & 335 & 346 & 328 & 343 \\
\hline Number of genera & 40 & 38 & 38 & 44 \\
\hline Number of species & 65 & 66 & 66 & 70 \\
\hline
\end{tabular}

\section{Results}

\subsection{Composition of foraminiferal assemblages}

A total of 1352 benthic foraminifera specimens belonging to 93 species and 53 genera, including hyaline-perforate, porcelaneous, and agglutinated taxa, were recovered from the samples collected in the Mamanguape estuary (Fig. 1 and Table 1). The foraminiferal tests obtained were found to be particularly well preserved, with even the most fragile forms in good condition, lacking signs of dissolution, abrasion, or breakage. Many specimens were found to contain pyrite framboids inside their tests, a feature considered to be indicative of anoxic conditions in the surrounding sediment (Fig. 9, figs. 22-23). Hyaline-perforate foraminifera comprise 34 genera $(64.2 \%$ of the total assemblage) and 53 species (57\% of the total assemblage), porcelaneous types account for 14 genera $(26.4 \%)$ and 33 species $(35 \%)$, and agglutinated taxa are represented by 5 genera $(9.4 \%)$ and 7 species $(8 \%)$. Percent abundances of wall structural types (agglu- 


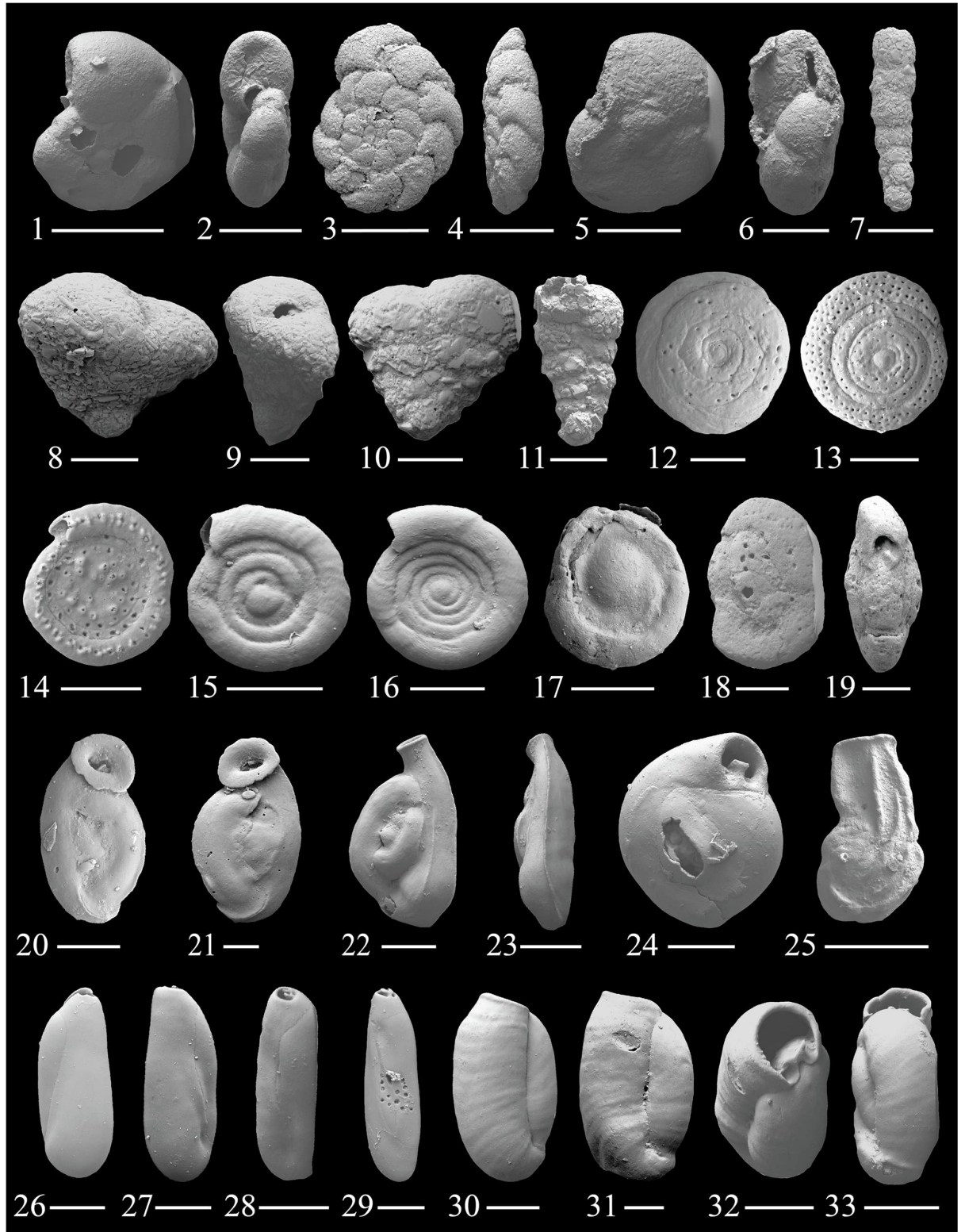

Figure 3. (1-2) Trochammina inflata (Montagu); (3-4) Rotaliammina trumbulli Seiglie; (5-6) Arenoparrella mexicana (Kornfeld); (7) Bigenerina sp. 1; (8-9) Textularia sp. 1; (10) Textularia cf. T. semialata Cushman; (11) Textularia sp. 2; (12) Mychostomina revertens (Rhumbler); (13-14) Spirillina grosseperforata Zheng; (15-16) Cornuspira involvens Reuss; (17) Cornuspira planorbis Schultze; (18-19) Fischerina sp. 1; (20-21) Wiesnerella auriculata (Egger); (22-23) Edentostomina sp. 1; (24) Adelosina milletti (Wiesner); (25) Articulina alticostata Cushman; (26-27) Pseudotriloculina sp. 1; (28-29) Pseudotriloculina sp. 2; (30-33) Pseudotriloculina sp. 3 . The scale bar is 100 and $50 \mu \mathrm{m}$ for figs. (8)-(14), (17)-(19), (21)-(24), and (26)-(29).

tinated, hyaline-perforate, and porcelaneous) do not show any significant variation among the sampling sites. Hyalineperforate foraminifera range between $72 \%$ and $75 \%$, porcelaneous foraminifera constitute $23 \%$ to $27 \%$, and agglutinated species contribute only $1 \%$ or $2 \%$ to the total assemblage at each site (Table 2). The total number of benthic foraminifera species increases slightly from sample site 1 near the mouth of the estuary (65 species) towards the innermost sample site 4 , where 70 species were recorded.

\subsection{Species richness and diversity}

Species richness values vary between $65-70$ among the sample sites (Table 1). The highest value (70 species) was recorded at site 4 and the lowest at site 1 (65 species). Fisher $\alpha$ values range between 24.04-26.60 (Table 2 and Fig. 3), with the highest values at site 4 and the lowest at site 1 . As a general trend, species richness and Fisher $\alpha$ values were found to increase from the sampling sites closer to the ocean 


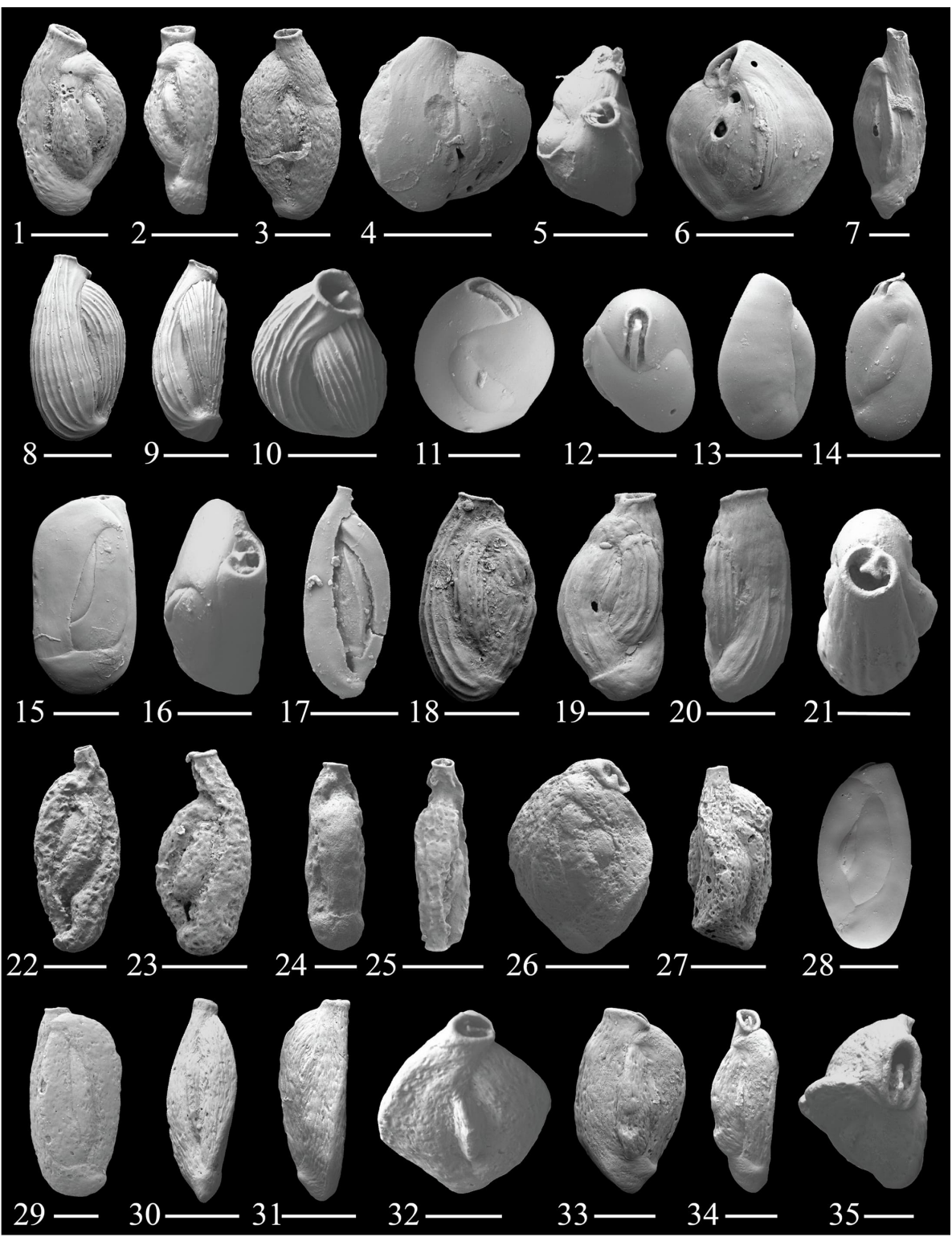

Figure 4. (1-3) Quinqueloculina cf. Q. compta Cushman; (4-6) Quinqueloculina cuvierina (d'Orbigny); (7) Quinqueloculina cf. Q. zhengi Parker; (8-10) Quinqueloculina poeyana d'Orbigny; (11-12) Pseudolachlanella eburnea (d'Orbigny); (13-14) Pseudolachlanella bermudezi (Acosta); (15-16) Quinqueloculina moynensis Collins; (17) Quinqueloculina quinquecarinata Collins; (18-21) Quinqueloculina cf. Q. rebeccae Vella; (22-25) Sigmoilinita costata Schlumberger; (26-27) Quinqueloculina samoensis Cushman; (28) Quinqueloculina tantabiddyensis Parker; (29) Quinqueloculina sp. 2; (30-32) Quinqueloculina sp. 1; (33-35) Quinqueloculina sp. 4. The scale bar is 100 and $50 \mu \mathrm{m}$ for figs. (11)-(12), (16), (21), (24), (26), (29), (30)-(31), and (33).

towards the inner parts of the estuary with the highest values at site 4 (Table 1 and Fig. 2). Dominance, evenness and the Shannon diversity index values recorded revealed only minor variability and were found to be comparatively uniform across all sample sites analyzed (Table 2).

\subsection{Distribution patterns}

Samples were found to have a comparatively uniform composition without much difference in species richness, species diversity, or community structure. The assemblages analyzed from each sampling site show a striking dominance of Pararotalia cananeiaensis $(20.7 \%-24.2 \%$ of the total assemblages). The second most abundant taxon is Orbitina carinata, a hyaline-perforate species with the highest percent abundances distant from the mouth of the estuary. Ammonia veneta and Anomalinulla sp. 1 are also abundant in all our samples, constituting $3.2 \%-7.5 \%$ and $4.9 \%$ $7.5 \%$ of the total assemblages, respectively. The porcela- 


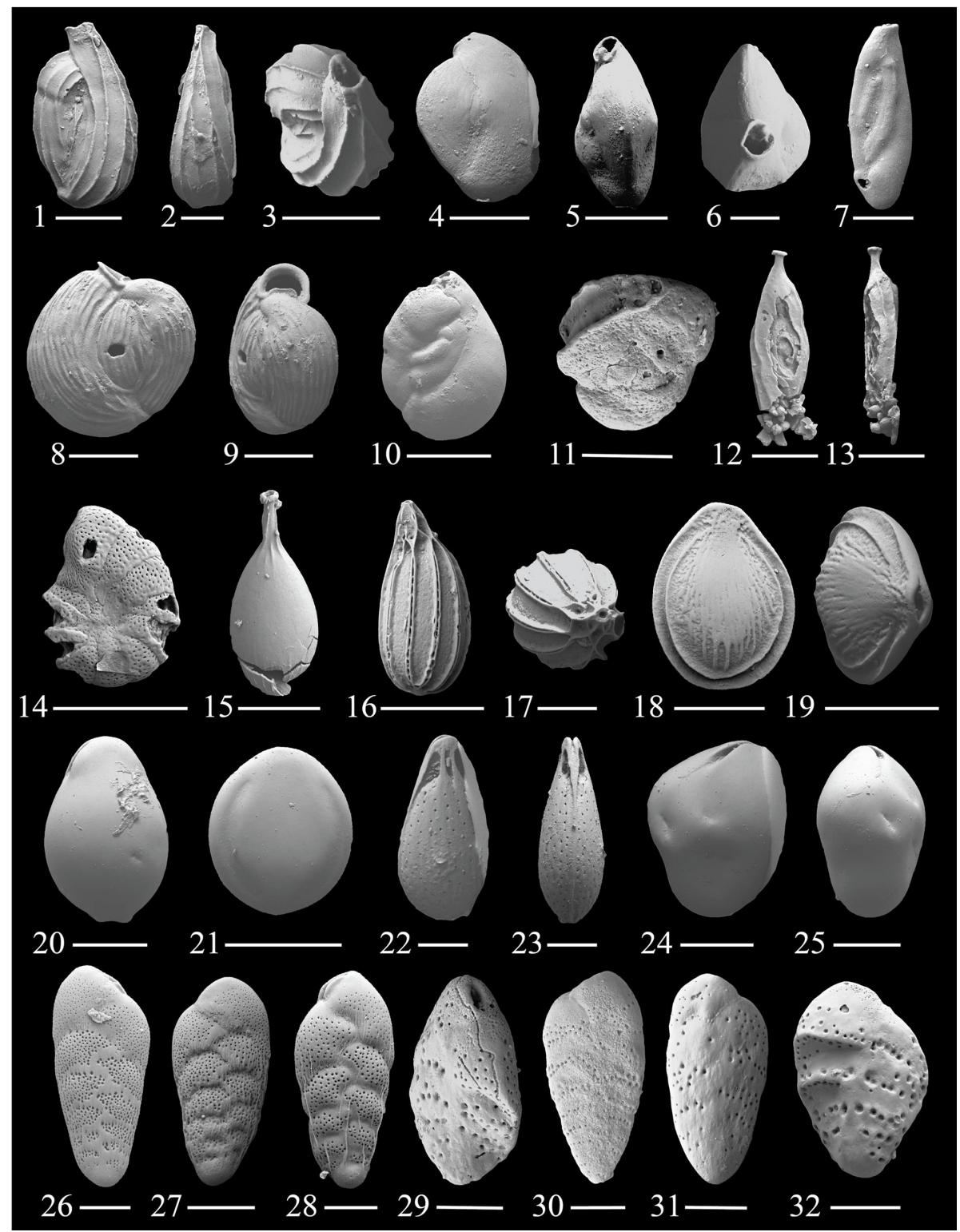

Figure 5. (1-3) Quinqueloculina cf. Q. carinatastriata Wiesner; (4-6) Quinqueloculina sp. 3; (7) Quinqueloculina cf. Q. bosciana d'Orbigny; (8-9) Miliolinella webbiana d'Orbingy; (10) Miliolinella sp. 1; (11) Hauerina atlantica Cushman; (12-13) Inaequalina sp. 1; (14) Laevipeneroplis bradyi Cushman; (15) Procerolagena oceanica (Albani); (16-17) Cushmanina bricei McCulloch; (18-19) Fissurina colomboensis McCulloch; (20) Fissurina bispinata Ujiié; (21) Fissurina sp. 2; (22-23) Fissurina semimarginata Reuss; (24-25) Fissurina? sp. 1; (26-28) Bolivina densipunctata Sellier de Civrieux; (29-32) Bolivina ordinaria Phleger and Parker. The scale bar is 100 and $50 \mu \mathrm{m}$ for figs. (2), (6)-(7), (17), (20), (22)-(25), (26), and (28)-(32).

neous species Quinqueloculina moynensis constitutes between $4.57 \%-6.36 \%$ of the total assemblage at individual sites. Species of the genus Quinqueloculina are represented in the assemblages by a highly diverse group and constitute 15 species. Among the 93 species recorded, a total of 40 species were present at all four sampling sites including the five most abundant species ( $P$. cananeiaensis, A. veneta, Anomalinulla sp. 1, O. carinata, and $Q$. moynensis).
Occurrence records of a few species display preferences for particular sites in the estuary. Among these, Angulogerina cf. A. occidentalis, Cribroelphidium mirum, and Elongobula parallela are particularly abundant at site 2,3 , and 4 , which correspond to the inner reaches of the estuary. Species recorded exclusively at sites located near the mouth region of the estuary (sites 1 and 2) include Anomalinulla glabrata, Bolivina densipunctata, Bolivina variabilis, Eoponidella pulchella, Fischerina sp. 1, Fissurina? sp. 1, Quin- 


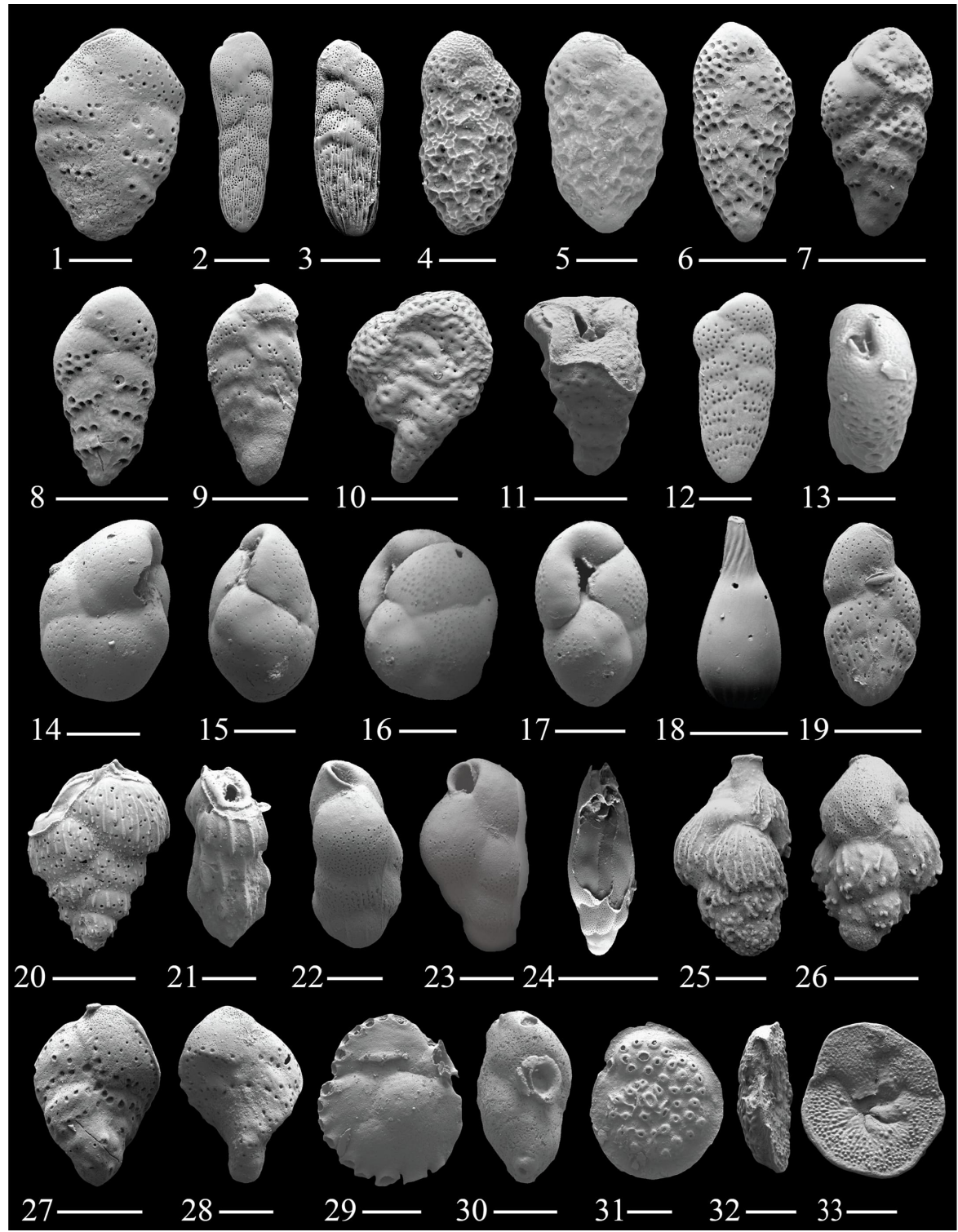

Figure 6. (1) Bolivina ordinaria Phleger and Parker; (2-3) Bolivina striatula Cushman; (4-5) Bolivina variabilis Williamson; (6-8) Bolivina cf. B. variabilis (Williamson); (9) Bolivina sp. 1; (10-11) Abditodentrix rhomboidalis (Millett); (12-13) Bolivina brevior Cushman; (1415) Globocassidulina rossensis Kennett; (16-17) Globocassidulina crassa (d'Orbigny); (18) Lagena tenuis Bornemann; (19) Loxostomina costulata (Cushman); (20-21) Sagrina pulchella d'Orbigny; (22-23) Cassidelina sp. 1; (24) Buliminella elegantissima (d'Orbigny); (2526) Angulogerina cf. A. occidentalis (Cushman); (27-28) Sigmavirgulina tortuosa (Brady); (29-30) Siphonina reticulata (Czjzek); (3133) Discorbitina pustulata (Heron-Allen and Earland). The scale bar is 100 and $50 \mu \mathrm{m}$ for figs. (1), (4)-(5), (12)-(17), (21)-(23), (25)-(26), and (28)-(33).

queloculina poeyana, $Q$. cf. $Q$. rebeccae, and $Q$. tantabiddyensis. Amphisteginid foraminifera, although present in low abundances, are also restricted to sample site 1 and 2 .

\section{Discussion}

Analyses of foraminiferal assemblages from the Mamanguape mangrove estuary revealed highly diverse, particularly species-rich, and structurally complex biota of benthic taxa.
With a total of 93 taxa, the species richness exceeds previous species counts and was found to be the highest among all true mangrove environments studied so far (see below and Fig. 2). In addition, our samples yielded unusual assemblages heavily dominated by calcareous taxa, lacking agglutinated specimens to a great degree, as reflected by the dominance of hyaline-perforate taxa that contribute between $72.3 \%$ $75.1 \%$ to the total population. Porcelaneous miliolids, representatives of shallow marine environments, constitute the 


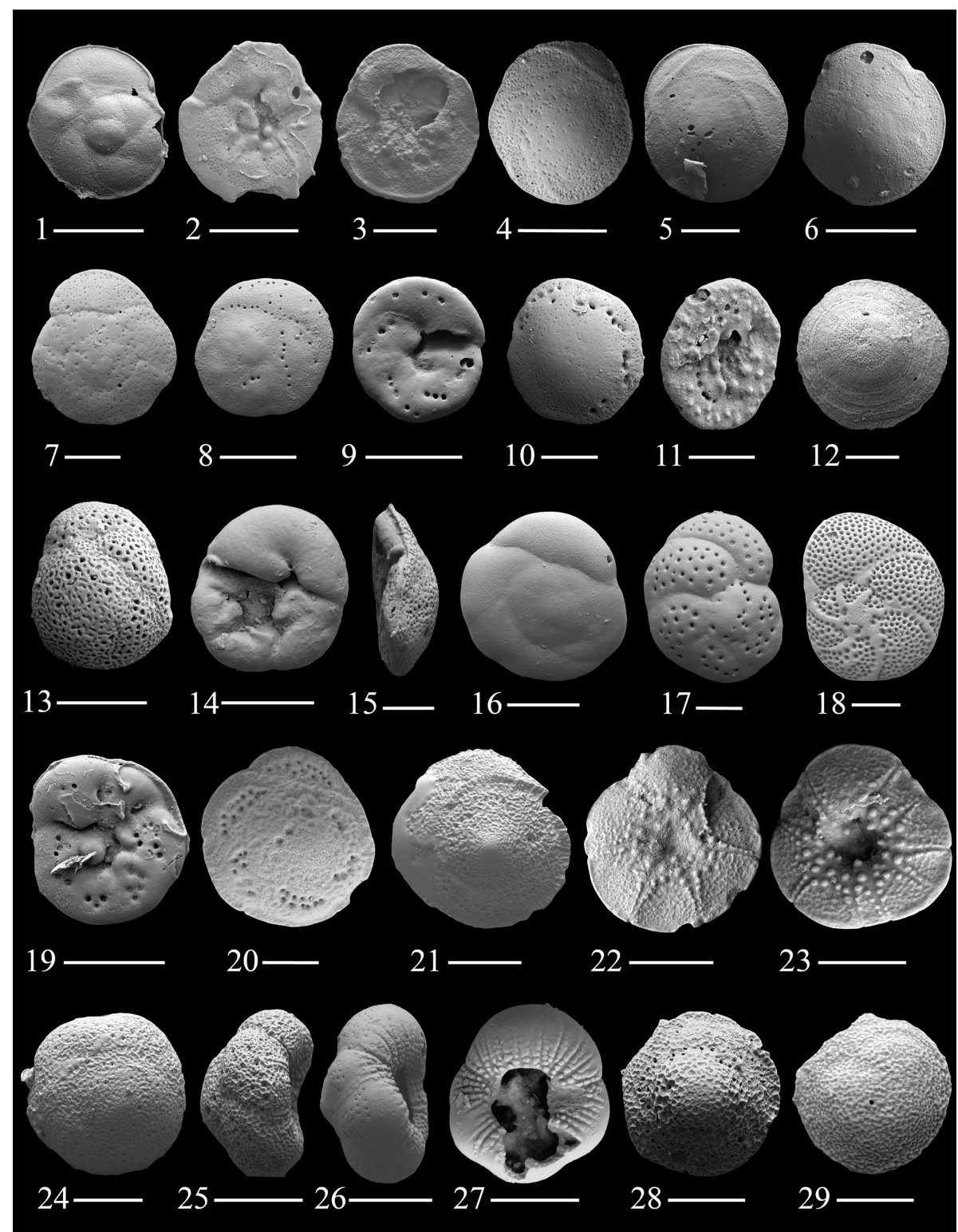

Figure 7. (1-3) Orbitina carinata Sellier de Civrieux; (4-6) Rotorbis auberii (d'Orbigny); (7-9) Neoconorbina sp. 1; (10-11) Neoconorbina radiatogranulata Parker; (12) Neoconorbina terquemi (Rzehak); (13-15) Rosalina bradyi (Cushman); (16) Rosalina sp. 1; (17-19) Rosalina sp. 2; (20-23) Glabratella carinata Seiglie and Bermúdez; (24-27) Glabratella mirabilis Seiglie and Bermúdez; (28-29) Glabratella carinata Seiglie and Bermúdez. The scale bar is 100 and $50 \mu \mathrm{m}$ for figs. (3)-(5), (7), (10)-(12), (14)-(15), (17), and (20)-(29).

second most abundant group with an abundance of $23.8 \%-$ $26.5 \%$. Agglutinated species, which are typically dominant in mangrove environments (Murray, 1991), contribute only $1.7 \%-2.1 \%$ to the total assemblages (Table 2). Species richness values recorded range between 65 and 70 at individual sites, whereas the average species richness was found to be generally much lower in other studies (Fig. 2; Debenay, 1990, 2001; Murray, 2006 and references therein). The atypical composition and highly diverse Mamanguape assemblages raise the question of which driving forces are decisive for the development of such unusual mangrove biota.
Because such assemblages rather resemble foraminiferal faunas from shallow coastal settings and are difficult to relate to mangrove habitats, the potential implications for the interpretation of the fossil record are considered.

As outlined above and illustrated in the Fisher $\alpha$ diagram (Fig. 2), the Mamanguape foraminiferal assemblages were found to deviate from usual foraminiferal mangrove biota in species richness, in the composition of wall-structural types, the presence of abundant hyaline-perforate and porcelaneous miliolid taxa, and in particularly low abundances of agglutinated species. While Fisher $\alpha$ value recordings 


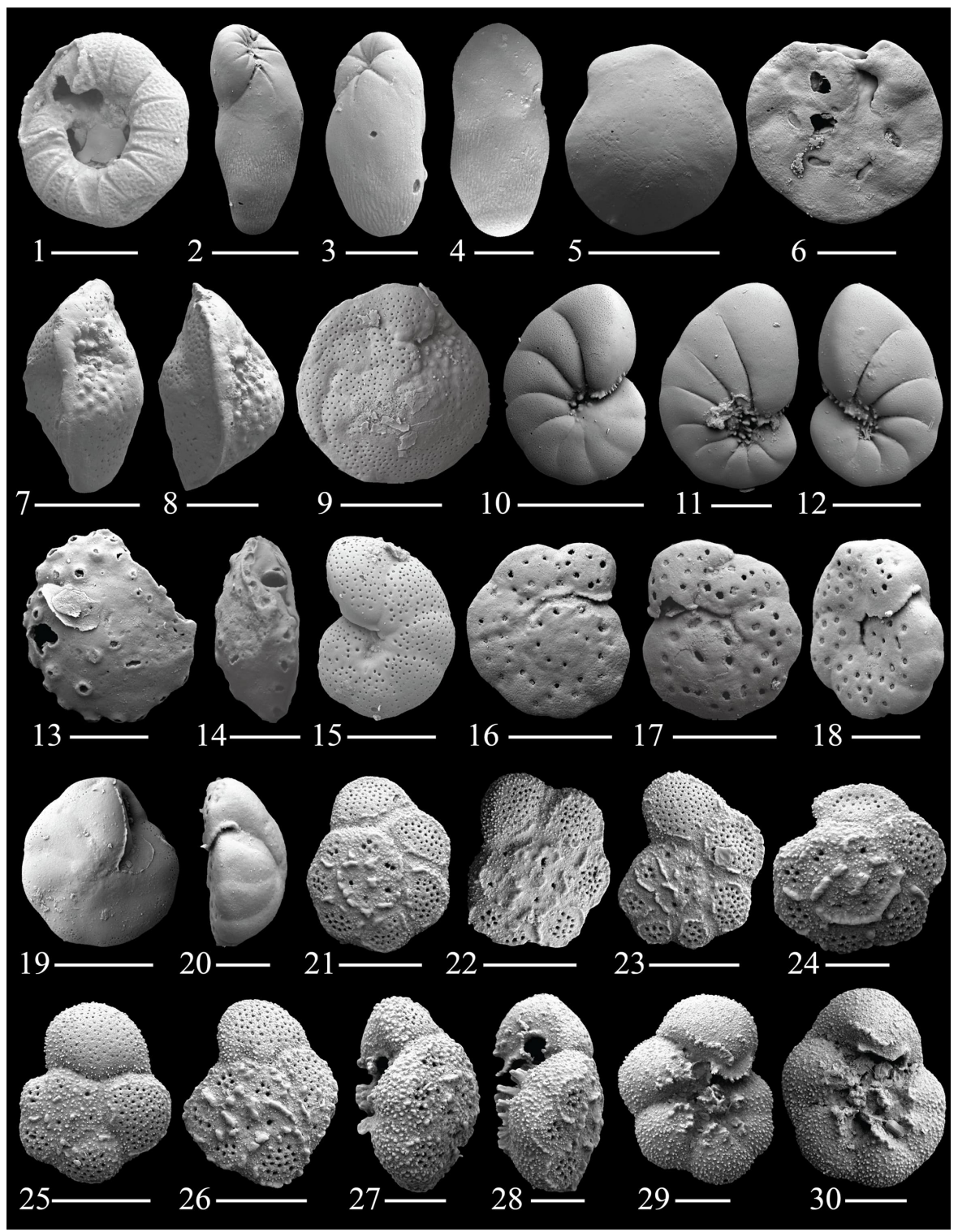

Figure 8. (1) Glabratella mirabilis Seiglie and Bermúdez; (2-4) Elongobula parallela (Cushman and Parker); (5-6) Eoponidella pulchella (Parker); (7-8) Amphistegina lessonii (d'Orbingy); (9) Amphistegina radiata (Fichtel and Moll); (10-12) Nonionides grateloupii (d'Orbingy); (13-14) Svratkina acuta (Sidebottom); (15) Anomalinulla glabrata (Cushman); (16-20) Anomalinulla sp. 1.; (21-30) Pararotalia cananeiaensis Debenay, Duleba, Bonetti De Melo e Souza \& Eichler. The scale bar is 100 and 50 $\mu \mathrm{m}$ for figs. (1), (3)-(4), (6)-(9), (13)-(14), (18)-(20), (24), and (27)-(30).

from previous mangrove studies ranged between 0.3 and 11, the Mamanguape faunas ranged between 24.4 and 26.6 (Fig. 2). The higher numbers are mainly due to the presence of both porcelaneous-miliolid and hyaline-perforate taxa and are more similar to values commonly encountered in coastal nearshore environments at the seaward end of river estuaries or in tropical lagoon or back-reef settings where foraminiferal diversity is much higher than in mangroves (Saunders, 1958; Halicz et al., 1984; Debenay et al., 2001; Langer and Lipps, 2003; Thissen and Langer, 2017; Langer et al., 2013; Fajemila et al., 2020a).
The composition of our benthic foraminifera assemblages also contrasts with the ones found in previous studies on total assemblages of mangrove foraminifera from the southern Atlantic, where benthic foraminifera assemblages are exclusively dominated by agglutinated and hyaline-perforate species and mostly lack porcelaneous taxa (Fig. 2; Murray, 1991, 2006). Agglutinated foraminifera within the Mamanguape mangroves contribute a mere $1 \%$ to $2 \%$ to the total assemblages, while other studies showed abundances that generally range above $40 \%$ (Culver, 1990; Brönniman et al., 1992; Debenay and Guillou, 2002; Murray, 2006). 


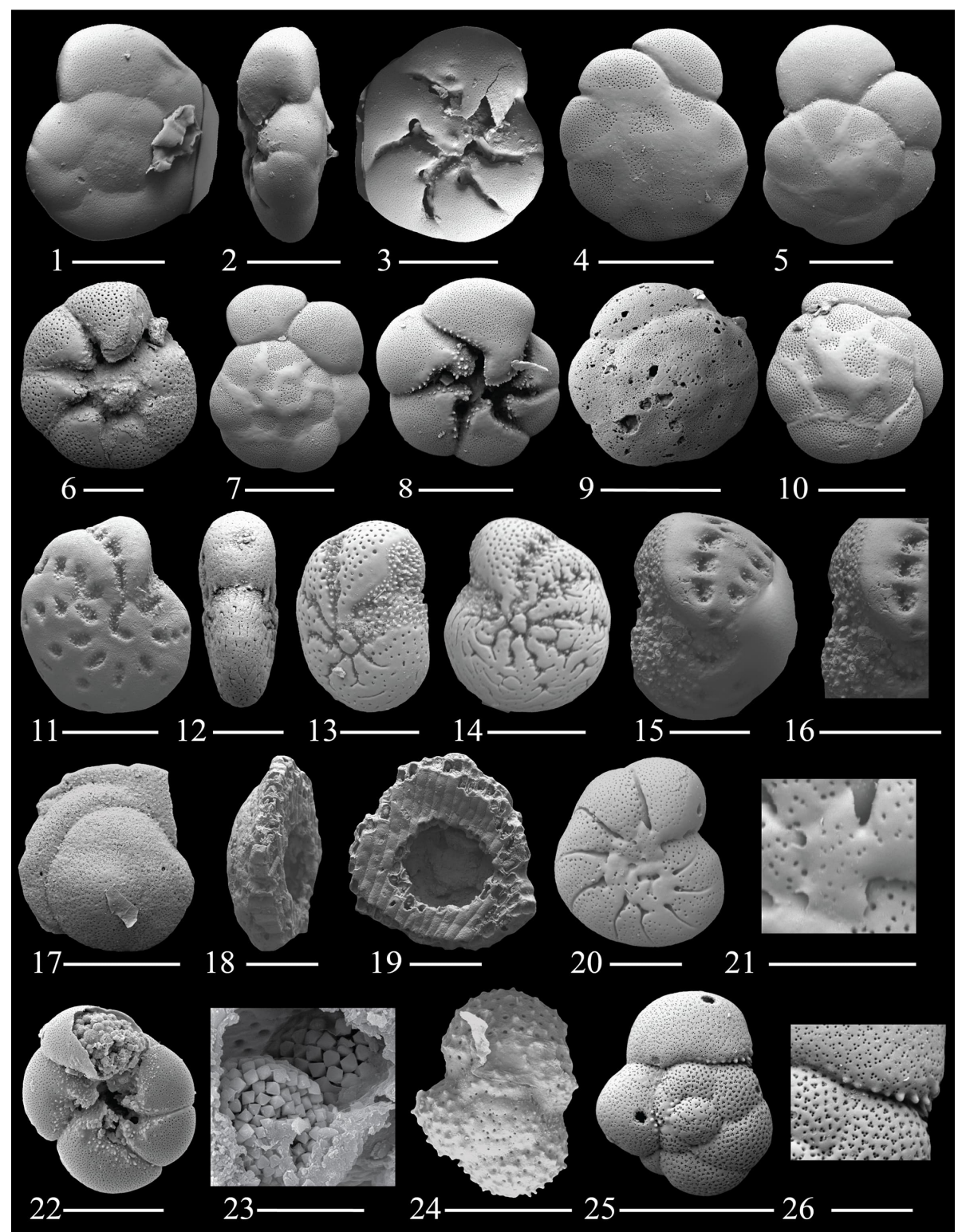

Figure 9. (1-3) Ammonia advena Cushman; (4-10) Ammonia veneta (Schultze); (11-14) Cribroelphidium mirum Langer and SchmidtSinns; (15-16) Elphidium sagrum (d'Orbingy); (17-19) Discorbis willamsoni Chapman and Parr; (20-21) Astrononion gallowayi Loeblich and Tappan; (22-23) Pyrite framboids found in our specimens, (24) Globigerinoides sp. 1; (25-26) Globigerinoides sp. 2. The scale bar is 100 and $50 \mu \mathrm{m}$ for figs. (6), (13), (15)-(16), and (18)-(20), $25 \mu \mathrm{m}$ for figs. (21) and (26), and $10 \mu \mathrm{m}$ for fig. (23).

Deviations from "typical" mangrove assemblages are also marked by the dominance and numerical abundance of Pararotalia cananeiaensis (Debenay et al., 2001), a taxon of a nearshore, shallow-water genus that is commonly not expected in large numbers in mangrove habitats (Geslin et al., 2002; Debenay et al., 2001). Within the Mamanguape mangroves, percent abundances of $P$. cananeiaensis were found to range between $20.1 \%$ and $24.2 \%$, making it the most abundant taxon of all species. Similar high abundances were recently reported by Damasio et al. (2020) from the Santos estuary (southeast Brazil), where the species was reported from the bay and along the main channel but absent from the low-saline northernmost mangrove habitats. Eichler et al. (1995) reported the species from the Bay of Trapandé (Brazil) and attributed its inshore occurrence to the marine influence. Similarly, Murray et al. (1982) attributed the upstream presence of small coastal species to be indicative of an upstream transport of sediment of marine origin. Debenay et al. (2001) studied in detail the occurrence and transportation of $P$. cananeiaensis along Brazilian coasts under variable hydrodynamic conditions. They associated the presence of $P$. cananeiaensis in estuary channels with the intensity of 
Table 2. Sample site information including geographical position, salinity (Medeiros et al., 2018), number of species, Fisher $\alpha$, Shannon's $H$, dominance (SID), evenness $\left(e^{H}\right) / S$, and percent abundances of the agglutinated, miliolid, and perforate specimens as well as the five most abundant species.

\begin{tabular}{lrrrr}
\hline & Sample 1 & Sample 2 & Sample 3 & Sample 4 \\
\hline Longitude & $6^{\circ} 46^{\prime} 59.61^{\prime \prime} \mathrm{S}$ & $6^{\circ} 46^{\prime} 57.84^{\prime \prime} \mathrm{S}$ & $6^{\circ} 47^{\prime} 57.89^{\prime \prime} \mathrm{S}$ & $6^{\circ} 46^{\prime} 55.93^{\prime \prime} \mathrm{S}$ \\
Latitude & $34^{\circ} 56^{\prime} 40.83^{\prime \prime} \mathrm{W}$ & $34^{\circ} 57^{\prime} 54.95^{\prime \prime} \mathrm{W}$ & $34^{\circ} 57^{\prime} 49.94^{\prime \prime} \mathrm{W}$ & $34^{\circ} 58^{\prime} 55.04^{\prime \prime} \mathrm{W}$ \\
Salinity \%o & $32 \pm 3.9$ & $30.3 \pm 3.9$ & $28.3 \pm 3.0$ & $28.7 \pm 3.1$ \\
Fisher $\alpha$ & 24.04 & 24.19 & 24.89 & 26.6 \\
Shannon H & 3.324 & 3.439 & 3.345 & 3.484 \\
Dominance D & 0.08149 & 0.0696 & 0.07689 & 0.06473 \\
Evenness $\left(e^{H}\right) / S$ & 0.4271 & 0.4721 & 0.4297 & 0.4656 \\
Agglutinated \% & 1.19 & 1.73 & 2.13 & 1.17 \\
Porcelaneous \% & 24.78 & 23.12 & 23.78 & 26.53 \\
Hyaline-perforate \% & 74.02 & 75.14 & 73.17 & 72.30 \\
Ammonia veneta \% & 7.46 & 3.18 & 3.35 & 5.83 \\
Anomalinulla sp. $1 \%$ & 7.46 & 4.91 & 5.49 & 4.96 \\
Orbitina carinata & 3.58 & 7.22 & 13.16 & 6.41 \\
Pararotalia cananeiaensis $\%$ & 24.18 & 21.97 & 22.87 & 20.70 \\
Quinqueloculina moynensis \% & 5.67 & 6.36 & 4.57 & 4.96 \\
\hline
\end{tabular}

marine intrusion into paralic systems and considered the upstream presence more likely to be a function of transport (allochthonous) than of in situ growth (see also Burone et al., 2006).

Seven different lines of evidence, however, strongly argue for an in situ deposition of assemblages and autochthonous presence of $P$. cananeiaensis, at least within the Mamanguape estuary. (i) Numerical abundances of $P$. cananeiaensis, Shannon's $H$, evenness, Fisher $\alpha$, and dominance index values do not vary substantially along the sampled transect and are largely uniform across the sample sites. Evidence for decreasing percent abundances upstream or features of successive filtering through the dense tributary mangrove channels is thus lacking. (ii) The Mamanguape River estuary is partially dammed by a natural sand barrier (Fig. 1) and acts as a hindrance in terms of water exchange and transport of coastal species deep into the estuary. (iii) Except for two individuals, planktic foraminifera are absent, thus arguing against a large-scale transport of open-ocean taxa upstream. (iv) The preservation of the taxa recovered ranges from good to excellent and includes both fragile, robust, smaller, and larger species. Features of abrasion, transport, or rolling over large distances were not observed. (v) The sample sites investigated all revealed a particularly high species richness of benthic foraminifera. (vi) The lack of both peneroplid and soritid foraminifera, two groups that are widely present in shallowwater nearshore biofacies in the region (Weinmann, 2009; Disaró et al., 2014), argues against a transport of species from nearshore to estuarine mangrove habitats. (vii) Pyrite framboids were frequently observed within the chambers in the majority of species, reflecting the presence of anoxic conditions at the site of deposition (see Fig. 9, figs. 22-23). Pyrite formation is tightly intertwined with the presence of organic matter (Berner, 1970, 1984; Thiel et al., 2019), suggesting that (a) foraminifera cell cytoplasm was present during deposition; (b) autolytic, bacterially, or prey-mediated protoplasm decay in foraminifera has been largely prevented (Murray and Bowser, 2000); and (c) foraminiferal assemblages are largely autochthonous. The time required for pyrite framboids to form the largest crystals, like the ones found in our assemblages, was previously estimated to be around $35 \mathrm{~d}$ (Rickard, 2019).

If a large-scale upstream transport of coastal species would indeed have taken place, a successive filtering and numerical reduction effect of coastal species through the dense mangrove stands would be expected. However, this has not been recorded in the assemblages. Instead, the number of benthic species was found to increase towards the inner parts of the estuary and the assemblages are therefore considered to be largely autochthonous.

Marine conditions supporting such diverse assemblages are manifested in high salinity values in our sampling area during both dry and wet seasons and are interpreted as the result of a longer residence time of marine waters in the estuary (Fig. 2; Dolbeth et al., 2016; Medeiros et al., 2018). Prevailing marine conditions within the dense Mamanguape mangrove estuary were also considered a major factor contributing to fish diversity in previous studies (MacDonald et al., 2008; Blaber, 2013).

The results obtained revealed unprecedentedly high species richness values and assemblages dominated by calcareous species instead of agglutinated forms and represent an atypical example for a mangrove benthic foraminiferal fauna when compared to previous studies. While these findings may seem puzzling at first sight, they are considered to mainly result from high salinity values in the upstream 
areas of the Mamanguape River estuary (Table 2). The resemblance to shallow-water nearshore foraminiferal communities is both indicated by the presence of a large number of porcelaneous miliolid and hyaline-perforate species and in the abundance of $P$. cananeiaensis. In addition, it should be noted that the low number of agglutinated specimens and species found in our assemblages is not an artifact of preservation, as samples were carefully treated and the material was picked immediately after transportation to the laboratory.

Salinity has long been recognized as a major driving force governing the species richness, composition of wall structural types, and diversity of foraminiferal assemblages (Murray, 1991; Debenay, 1990). A distinct separation between agglutinated and calcareous taxa along a pronounced salinity gradient has recently been reported from Lagos Lagoon, where mangrove and low salinity environments are dominated by agglutinated foraminifera (Fajemila et al., 2020b). While the majority of mangrove assemblages from along the Atlantic coast of South America were reported to be dominated by agglutinated taxa, the Mamanguape mangrove estuary was found to contain abundant calcareous wall types and to be almost devoid of agglutinated taxa. Among the environmental framework conditions promoting such atypical mangrove assemblages of foraminifera, salinity stands out as a prominent control factor. Salinity recordings along the sampling traverse revealed values ranging between $\sim 25 \%$ and $35 \%$ o, indicating mostly euhaline to brackish water conditions. The prevalence of marine conditions within the studied area of the Mamanguape estuary is supported by comparatively long residence times of marine waters, high tidal amplitudes, and semi-diurnal tidal flushing of the estuarine environment. The resemblance of the atypical mangrove assemblages to shallow-water nearshore biota may thus be attributed to the intensity of marine conditions, where calcareous foraminifera dominate over agglutinated taxa (Boltovskoy, 1954; Todd and Brönnimann, 1957; Boltovskoy and Hincapié de Martínez, 1983; Scott et al., 1990; Debenay, 2001; Debenay et al., 2002, 2004; Moreno et al., 2005; Eichler et al., 2007; Camacho et al., 2015; Shaw et al., 2016; Passos et al., 2017). The penetration of calcareous species into the Mamanguape estuary has also been reported from the neighboring Paraíba estuary (Debenay et al., 2002). However, unlike the Mamanguape estuary, the Paraíba estuary receives freshwater discharge from more rivers and invasions of marine foraminifera only occur during the dry season and completely disappear during the rainy season (Debenay et al., 2002).

Independent of whether the foraminiferal assemblages are allochthonous or autochthonous, the atypical Mamanguape mangrove faunas raise questions concerning implications for the interpretations of the fossil record. Unlike previous studies on foraminifera from South American and many other mangrove environments around the world, where specialized agglutinated taxa dominated mangrove environments, excep- tionally species-rich and diverse assemblages of foraminifera prevail within the dense mangroves at Mamanguape. Both Debenay et al. (2001, 2002) and Woodroffe et al. (2005) demonstrated that a range of environmental factors jointly govern both the composition, distribution, and preservation of foraminiferal biota in mangrove environments. Besides salinity, these include the elevation, grain size, organic content, and taphonomic processes related to low $\mathrm{pH}$ excursions resulting in the removal of agglutinated and calcareous taxa. Post-mortem disaggregation and taphonomic loss may thus bias the fossil record and constitute a serious constraint regarding paleoenvironmental reconstructions.

Mangrove ecosystems have existed at least since the Late Cretaceous and fossil evidence used for paleoecological reconstructions is mostly based on organic remains (fruit; flowers; wood or leaves; or microfossils, particularly pollen; Ellison et al., 1999) and sedimentological features (Augustinus, 1995). Sedimentation of typical fine-grained mangrove deposits results from the reduction in current velocity where tree trunks, prop roots and pneumatophores exercise a filter function and result in typical mangrove mud sediments. Within the Mamanguape estuary, the accumulation and vertical accretion of mangrove mud is a mixture of river-born clastic sediments, organic material produced by mangrove trees and associated fauna, and suspension-rich ocean floating debris penetrating mangrove swamps. In high precipitation areas and under low salinity conditions, the production of organic material is generally promoted but reduces $\mathrm{pH}$ conditions within the sediment and limits carbonate availability and thus reproduction of calcareous foraminifera. On the other hand, agglutinated tests are known to resist low $\mathrm{pH}$ conditions and dissolution while they are removed through oxidation-reduction reactions (Ellison and Nichols, 1976; Scott and Medioli, 1978; Boltovskoy, 1984; Goldstein, 1988 and the references therein; Thomas and Varekamp, 1991; Debenay et al., 2002, 2004). However, in the absence of considerable rainfall and during the warm periods, penetration of coastal waters into the estuarine system occurs. Based on the intensity of the marine influence and tides, calcareous foraminifera start to dominate and get preserved in the otherwise brackish or freshwater realm (Boltovskoy, 1954; Todd and Brönnimann, 1957; Scott et al., 1990; Debenay, 2001; Debenay et al., 2002, 2004; Moreno et al., 2005; Eichler et al., 2007; Camacho et al., 2015; Shaw et al., 2016; Passos et al., 2017; Woodroffe et al., 2005). Normally, salinity tends to be higher in the downstream areas in estuaries, yet the upstream areas of the Mamanguape are characterized by high salinity (Table 2), indicative of a consistent influence of oceanic waters penetrating even further upstream of the sampling sites. 


\section{Conclusions}

Mangrove environments of the Mamanguape River estuary are home to diverse assemblages of benthic foraminifera including 33 porcelaneous, 53 hyaline-perforate, and 7 agglutinated species and represent an extraordinary ecosystem characterized by atypical, highly diverse, and species-rich benthic foraminiferal biota. The atypical population structure features prominent components of hyaline-perforate and miliolid-porcelaneous benthic foraminifera and are unprecedented in previous mangrove studies. The assemblages resemble coastal nearshore biota that are traditionally not classified as mangrove foraminiferal faunas and are here considered to be the result of highly saline ocean waters consistently penetrating deep into the estuary and promoting the presence of compositionally diverse and species-rich biota. When preserved in the fossil record, such assemblages are not readily related to mangrove ecosystems and would most likely be interpreted as a coastal, nearshore, shallow-water environment. Our findings thus have implications for inferring environmental conditions of past mangrove ecosystems. Salinity was found to be the main controlling factor structuring benthic foraminiferal assemblages, where both the comparatively long residence time of marine waters and the low freshwater inflow support prevailing euhaline to brackish water conditions and the presence of calcareous-dominated, species-rich foraminiferal assemblages.

Code availability. The PAST software of Hammer et al. (2001) is available at: https://www.nhm.uio.no/english/research/ infrastructure/past/.

Data availability. All data used in the present study are provided in Tables 1 and 2.

Author contributions. MRL conceptualized the study and collected the material. NS and MRL analyzed the data and prepared and wrote the manuscript.

Competing interests. The authors declare that they have no conflict of interest.

Disclaimer. Publisher's note: Copernicus Publications remains neutral with regard to jurisdictional claims in published maps and institutional affiliations.

Acknowledgements. We are grateful to the reviewers and the editor for their constructive comments and suggestions. We also thank Stephanie Pietsch for assistance with the collection of the material and Georg Oleschinski for the SEM pictures of the framboidal pyrite. The analysis and study of the material was supported by a grant from the German Federal Foreign Office and the University of Bonn.

Financial support. This open-access publication was funded by the University of Bonn.

Review statement. This paper was edited by Hiroshi Kitazato and reviewed by Johann Hohenegger and one anonymous referee.

\section{References}

Alongi, D.: Mangrove forests: Resilience, protection from tsunamis, and responses to global climate change, Estuar. Coast. Shelf S., 76, 1-13, https://doi.org/10.1016/j.ecss.2007.08.024, 2008.

Alongi, D., Wattayakorn, G., Boyle, S., Tirendi, F., Payn, C., and Dixon, P.: Influence of roots and climate on mineral and trace element storage and flux in tropical mangrove soils, Biogeochemistry, 69, 105-123, https://doi.org/10.1023/B:BIOG.0000031043.06245.af, 2004.

Alves, F. C.: Análise morfoestrutural das bacias dos rios e Mamanguape (PB) com base em MDE-SRTM e imagem PALSAR/ALOS-1, MSc Diss., Inst. Nac. Pes. Esp., INPE, 5 151 pp., available at: http://mtc-m16d.sid.inpe.br/col/sid.inpe. br/mtc-m19/2015/02.26.13.32/doc/publicacao.pdf (last access: 29 June 2021), 2015.

Augustinus, P. G. E. F.: Geomorphology and Sedimentology of Mangroves: Geom. Sediment, Est., 53, 333-357, 1995.

Barbosa, C. F., Scott D. B., Seoane J. C. S., and Turcq, B. J.: Foraminiferal zonations as base lines for Quaternary sealevel fluctuations in south-southeast Brazilian mangroves and marshes, J. Foramin Res., 35, 22-43, 2005.

Belart, P., Renan, H., Raposo, D., Martins, V., Frontalini, F., Figueiredo, M., Lorini, M. L., and Laut, L.: Seasonal Dynamics of Benthic Foraminiferal Biocoenosis in the Tropical Saquarema Lagoonal System (Brazil), Estuar. Coast., 42, 1-20, 2019.

Berner, R. A.: Sedimentary pyrite formation, Am. J. Sci., 268, 1-23, 1970.

Berner, R. A.: Sedimentary pyrite formation - An update, Geochim. Cosmochim. Ac., 48, 605-615, 1984.

Bezerra, D., Nascimento, D., Ferreira, E., Rocha, P., and Mourão, J.: Influence of tides and winds on fishing techniques and strategies in the Mamanguape River Estuary, Paraíba State, NE Brazil, Anais da Academia Brasileira de Ciências, 84, 775-88, 10.1590/S0001-37652012005000046, 2012.

Bezerra, F. H., Amaro, V. E., Vita-Finze, C., and Saady, A.: Pliocene-Quaternary fault control of sedimentation and coastal plain morphology in NE Brazil, J. S. Am. Earth Sci., 14, 61-75, https://doi.org/10.1016/S0895-9811(01)00009-8, 2001.

Blaber, S. J. M.: Fishes and fisheries in tropical estuaries: the last 10 years, Estuar Coast Shelf S., 135, 57-65, 2013.

Boltovskoy, E.: Foraminíferos del Golfo San Jorge. Rev. Inst. Nac. Investig. Cien. Nat. Mus. Argen. Cien. Nat. "Bernardino Rivadavia”, Cien. Geol., III, Buenos Aires, 3, 79-246, 1954.

Boltovskoy, E.: Foraminifera of mangrove swamps, Physis A, 42, $1-9,1984$. 
Boltovskoy, E. and Hincapié de Martínez, S.: Foraminiferos del manglar de Tesca, Cartagena, Colombia. Rev. Esp. Micropal., 15, 205-220, 1983.

Brönnimann, P., Dias-Brito, D., and Moura, J., A.: Foraminiferos da Facies Mangue Da Planicie de Mare de Guaratiba, Rio de Janeiro, Brasil, Anais do Congresso Latino-Americano de Paleontologia, Porto Alegre, 2, 877-891, 1981.

Brönnimann, P., Whittaker, J. E., and Zaninetti, L.: Brackish water foraminifera from mangrove sediments of southwest Viti Levu, Fiji Islands, Southwest Pacific, Rev. Paléobiol., 11, 13-65, 1992.

Burone, L., Venturini, N., Sprechmann, P., Valente, P., and Muniz, P.: Foraminiferal responses to polluted sediments in the Montevideo coastal zone, Uruguay, Mar. Pollut. Bull., 52, 61-73, 2006.

Call, M., Maher, D., Ruiz-Halpern, S., Mangion, P., Erler, D., Oakes, J., Rosentreter, J., Murray, R., and Eyre, B.: Spatial and temporal variability of carbon dioxide and methane fluxes over semi-diurnal and spring-neap-spring timescales in a mangrove creek, Geochim. Cosmochim. Ac., 150, 211-225, https://doi.org/10.1016/j.gca.2014.11.023, 2015.

Camacho, S., Moura, D., Connor, S., David, S., and Boski, T.: Ecological zonation of benthic foraminifera in the lower Guadiana Estuary (southeastern Portugal), Mar. Micropaleontol., 114, 118, https://doi.org/10.1016/j.marmicro.2014.10.004, 2015.

Cunha-Lignon, M., Coelho-Jr., C., Almeida, R., Menghini, R., Correa, F., Schaeffer-Novelli, Y., Cintrón-Molero, G., and DahdouhGuebas F.: Mangrove Forests and Sedimentary Processes on the South Coast of São Paulo State (Brazil), J. Coast. Res., Spec. Iss., 56, 405-409, 2009.

Cushman, J. A. and Brönnimann, P.: Some new genera and species of foraminifera from brackish water of Trinidad, Contr. Lab. Foram. Res., 24, 15-21, 1948a.

Cushman, J. A. and Brönnimann, P.: Additional new species of arenaceous Foraminifera from shallow waters of Trinidad, Contr. Lab. Foram. Res., 24, 37-42, 1948b.

Culver, S.: Benthic Foraminifera of Puerto Rican MangroveLagoon Systems: Potential for Paleoenvironmental Interpretations, Palaios, 5, 34-51, https://doi.org/10.2307/3514995, 1990.

Damasio, B., Timoszczuk, C., Kim, B. S. M., Sousa, S., Bicego, M., Siegle, E., and Figueira, R.: Impacts of hydrodynamics and pollutants on foraminiferal fauna distribution in the Santos Estuary (SE Brazil), J. Sediment. Environ., 5, 61-86, https://doi.org/10.1007/s43217-020-00003-w, 2020.

Debenay, J. P.: Recent foraminiferal assemblages and their distribution relative to environmental stress in the paralic environments of West Africa (Cape Timiris to Ebrie Lagoon), J. Foramin. Res., 20, 267-282, 1990.

Debenay, J. P.: Foraminiferal assemblages in a hypersaline lagoon, Araruama (RJ) Brazil, J. Foramin. Res., 31, 133-151, 2001.

Debenay, J. P. and Guillou, J. J.: Ecological transitions indicated by foraminiferal assemblages in paralic environments, Estuaries, 25, 1107-1120, 2002.

Debenay, J. P., Duleba, W., Bonetti, C., De, S., Souza, M., and Eichler, B.: Pararotalia cananeiaensis n. sp.: Indicator of marine influence and water circulation in Brazilian coastal and paralic environments, J. Foramin. Res., 31, 152-163, 2001.

Debenay, J. P., Guiral, D., and Parra, M.: Ecological Factors Acting on the Microfauna in Mangrove Swamps. The Case of Foraminiferal Assemblages in French Guiana, Estuar. Coast.
Shelf S., 55, 509-533, https://doi.org/10.1006/ecss.2001.0906, 2002.

Debenay, J. P., Guiral, D., and Parra, M.: Behaviour and taphonomic loss in foraminiferal assemblages of mangrove swamps of French Guiana, Mar. Geol., 208, 295-296, 2004.

Disaró, S. T., Totah, V. I., Watanabe, S., Ribas, E. R., and Pupo, D. V.: Biodiversidade Marinha da Bacia Potiguar: Foraminifera, Mus. Nacional, Rio de Janeiro, 1-218, 2014.

Dolbeth, M., Vendel, A. L., Baeta, A., Pessanha, A., and Patrício, J.: Exploring ecosystem functioning in two Brazilian estuaries with fish richness, traits and food webs, Mar. Ecol.-Prog. Ser., 560, 41-55, https://doi.org/10.3354/meps11895, 2016.

Eichler, P.: Foraminiferal zonation from a subtropical mangrove in Bertioga Channel (São Paulo, SP, Brazil), Reg. Stud. Mar. Sci., 25, 100460, https://doi.org/10.1016/j.rsma.2018.100460, 2018.

Eichler, B. B., Debenay, J. P., Bonetti, C., and Duleba, W.: Distribution of benthic foraminifera in the southwestern zone of the estuarine-lagoonal system of Iguapé-Cananéia (Brazil), Bol. Inst. Oceanogr., 43, 1-17, https://doi.org/10.1590/S0373$55241995000100001,1995$.

Eichler, P. P. B., Eichler, B. B., De Miranda, L. B., and Rodrigues, A. R.: Modern foraminiferal facies in a subtropical estuarine Channel, Bertioga, São Paulo, Brazil, J. Foramin. Res., 37, 234 247, 2007.

Eichler, P., Rodrigues, A., Pereira, E., Eichler, B., Kahn, A., and Vital, H.: Foraminifera as Environmental Condition Indicators in Todos os Santos Bay (Bahia, Brazil), Open J. Ecol., 5, 326-342, https://doi.org/10.4236/oje.2015.57027, 2015.

Eichler, P., Gomes, C., Costa, R., Corrêa, A., Gomes, M., and Vital, H.: Foraminifera Distribution in Itapitangui River Mangrove, Cananeia (Sao Paulo, Brazil) and its Environmental Relations, Modern Approaches in Oceanography and Petrochemical Sciences, 3, 219-224, 2019.

Ellison, A., Farnsworth, E., and Merkt, R. E.: Origins of mangrove ecosystems and the mangrove biodiversity anomaly, Global Ecol. Biogeogr., 8, 95-115, 1999.

Ellison, R. L. and Nichols, M. M.: Modern and Holocene foraminifera in the Chesapeake Bay region, in: First International Symposium on Benthonic Foraminifera of the Continental Margins, edited by: Schafer, C. T. and Pelletier, B. R., 14 Part A Ecology and Biology: Marit. Sed., Spec. Publ., 1, 131-151, Halifax, Nova Scotia, Canada, 1976.

Fajemila, O. T. and Langer, M. R.: Spatial distribution and biogeographic significance of foraminiferal assemblages from São Tomé and Príncipe, Gulf of Guinea, West Africa, Neues Jahrb. Geol. Paläontol., 285, 337-360, https://doi.org/10.1127/njgpa/2017/0686, 2017.

Fajemila, O. T., Langer, M. R., and Lipps, J. H.: Spatial Patterns in the Distribution, Diversity and Abundance of Benthic Foraminifera around Moorea (Society Archipelago, French Polynesia), PLoS One, 10, e0145752, https://doi.org/10.1371/journal.pone.0145752, 2015.

Fajemila, O. T., Langer, M. R., and Lipps, J. H.: Atlas of ShallowWater Tropical Benthic Foraminifera from Moorea (Society Islands, French Polynesia), Cushman Found. Foram. Res., Spec. Publ., 48, 1-107, 2020a.

Fajemila, O. T., Sariaslan, N., and Langer, M. R.: Spatial distribution of benthic foraminifera in the Lagos Lagoon (Nigeria): Trac- 
ing the impact of environmental perturbations, PLoS One, 15, e0243481, https://doi.org/10.1371/journal.pone.0243481, 2020 b.

Fisher R. A., Corbet A. S., and Williams, C. B.: The relationship between the number of species and the number of individuals in a random sample of animal populations, J. Anim. Ecol., 12, 42$58,1943$.

Gasparini, S. and Vilela, C.: Paleoenvironmental evolution based on benthic foraminifera biofacies of the Paraíba do Sul Deltaic Complex, eastern Brazil, J. S. Am. Earth Sci., 80, 291-303, https://doi.org/10.1016/j.jsames.2017.09.026, 2017.

Geslin, E., Debenay, J. P., Duleba, W., and Bonetti, C.: Morphological abnormalities of foraminiferal tests in Brazilian environments: comparison between polluted and non-polluted areas, Mar. Micropaleontol., 45, 151-168, 2002.

Gillanders, B. M., Elsdon, T. S., Halliday, I. A., Jenkins, G. P., Robins, J. B., and Valesini, F. J.: Potential effects of climate change on Australian estuaries and fish-utilising estuaries: a review, Mar. Freshwater Res., 62, 1115-1131, https://doi.org/10.1071/MF11047, 2011.

Goldstein, S. T.: Foraminifera of relict salt marsh deposits, St. Catherines Island, Georgia: Taphonomic implications Palaios, 3, 327-334, 1988.

Gleeson, J., Santos, I. R., Maher, D. T., and Golsby-Smith, L.: Groundwater-surface water exchange in a mangrove tidal creek: evidence from natural geochemical tracers and implications for nutrient budgets, Mar. Chem., 156, 27-37, 2013.

Hammer, Ø., Harper, D. A. T., and Ryan, P. D.: PAST: Paleontological statistics software package for education and data analysis, Palaeontol. Electrol., 4, 1-9, 2001 (software available at: https: //www.nhm.uio.no/english/research/infrastructure/past/, last access: 30 June 2021).

Halicz, E., Noy, N., and Reiss, Z.: Foraminifera from Shura Arwashie mangrove (Sinai), in: Hydrobiology of the mangal, edited by: Por, F. D. and Dor, I., Dr. W. Junk Publ., The Hague, 145149, 1984.

Hiltermann, H., Brönnimann, P., and Zaninetti, L.: Neue Biozönosen in den Sedimenten der Mangrove bei Acupe, Bahia, Brasilien, Notes Lab. Pal. Univ. Geneve, 8, 1-6, 1981.

Instituto Brasileiro de Geografia e Estatistica: Population Estimates for the cities Mamanguape, Rio Tinto and Marcação, available at: https://www.ibge.gov.br/en/cities-and-states.html?view= municipio (last access: 1 February 2021), 2019.

Langer, M. and Lipps, J.: Foraminiferal distribution and diversity, Madang Reef and Lagoon, Papua New Guinea, Coral Reefs, 22, 143-154, https://doi.org/10.1007/s00338-003-0298-1, 2003.

Langer, M., Thissen, J., Makled, W., and Weinmann, A.: The Foraminifera from the Bazaruto Archipelago (Mozambique), Neues Jahrb. Geol. Paläontol., 267, 155-170, https://doi.org/10.1127/0077-7749/2013/0302, 2013.

Langer, M. R. and Lipps, J. H.: Assembly and persistence of foraminifera in introduced mangroves on Moorea, French Polynesia, Micropaleontology, 52, 343-355, 2006.

Langer, M. R., Hottinger, L., and Huber, B.: Functional Morphology in Low-Diverse Benthic Foraminiferal Assemblages from TidalFlats of the North Sea, Senck. Marit., 20, 81-99, 1990.

Langer, M. R., Fajemila, O. T., and Mannl, S.: Assemblages of recent intertidal mangrove foraminifera from the Akanda National Park, Gabon: sea level proxies preserved in faunal assemblages, Neues Jahrb. Geol. Paläontol., 281, 327-338, 2016.
Laut, L. L. M., Martins, V., da Silva, F. S., Crapez, M. A. C., Fontana, L. F., Carvalhal-Gomes, S. B. V., and Souza, R. C. C. L.: Foraminifera, thecamoebians, and bacterial activity in polluted intertropical and subtropical Brazilian estuarine systems, J. Coast. Res., 32, 56-69, 2016.

Leonel, R. M. V., Lopes, S. G. B. C., and Aversari, M.: Distribution of wood-boring bivalves in the Mamanguape river estuary, Paraíba, Brazil, J. Mar. Biol. Assoc., 82, 1039-1040, 2002.

Leopold, A., Marchand, C., Deborde, J., and Allenbach, M.: Water Biogeochemistry of a Mangrove-Dominated Estuary Under a Semi-Arid Climate (New Caledonia), Estuar. Coast., 40, 773 791, https://doi.org/10.1007/s12237-016-0179-9, 2017.

Li X., Burnett W., and Chanton, J.: Submarine Ground Water Discharge Driven by Tidal Pumping in a Heterogeneous Aquifer, Ground Water, 47, 558-568, https://doi.org/10.1111/j.17456584.2009.00563.x, 2009.

Lipps, J. and Langer, M.: Benthic Foraminifera from the Meromictic Mecherchar Jellyfish Lake, Palau (Western Pacific), Micropaleontology, 45, 278-284, https://doi.org/10.2307/1486137, 1999.

MacDonald, J. A., Glover, T., and Weis, J. S.: The impact of mangrove prop-rootepibionts on juvenile reef fishes: afield experiment using artificial roots and epifauna, Estuar. Coast., 31, 981, https://doi.org/10.1007/s12237-008-9083-2, 2008.

Martins, V., Laut, L., Frontalini, F., Sequeira, C., Rodrigues, R., Fonseca, M., Bergamaschi, S., Pereira, E., Delavy, F., Figueiredo Jr., A., Miranda, P., Terroso, D., Pena, A., Laut, V., Figueira, R., and Rocha, F.: Controlling Factors on the Abundance, Diversity and Size of Living Benthic Foraminifera in the NE Sector of Guanabara Bay (Brazil), J. Sediment. Environ., 1, 393-410, https://doi.org/10.12957/jse.2016.26872, 2016.

Medeiros, A. P. M., Xavier, J. H. D. A., Da Silva, M. B., AiresSouza, L., and Rosa, I. M. D. L.: Distribution patterns of the fish assemblage in the Mamanguape River Estuary, North-eastern Brazil, Mar. Biol. Res., 14, 524-536, 2018.

Moreno, J., Fatela, F., Andrade, C., Cascalho, J., Moreno, F., and Drago, T.: Living foraminiferal assemblages from the Minho and Coura estuaries (Northern Portugal): a stressful environment, Thalassas, 21, 17-28, 2005.

Murray, J.: Ecology and applications of benthic foraminifera, Cambridge University Press, 426 pp., 2006.

Murray, J. J. and Bowser, S. S.: Mortality, protoplasm decay rate, and reliability of staining techniques to recognize "living" foraminifera: a review, J. Foramin. Res., 30, 66-70, 2000.

Murray, J. W.: Distribution and Ecology of Living Benthic Foraminiferids, Heinemann Educational Books, London, 274 pp., 1973.

Murray, J. W.: Ecology and Palaeoecology of Benthic Foraminifera, Longman, Harlow, 397 pp., 1991.

Murray, J. W., Sturrock, S., and Weston J.: Suspended load transport of foraminiferal tests in a tide- and wave-swept sea, J. Foramin. Res., 12, 51-85, 1982.

Nascimento, D., Alves, A. G., Alves, R., Barboza, R., Diele, K., and Mourão, J.: An examination of the techniques used to capture mangrove crabs, Ucides cordatus, in the Mamanguape River estuary, northeastern Brazil, with implications for management, Ocean Coast Manage., 130, 50-57, https://doi.org/10.1016/j.ocecoaman.2016.05.010, 2016.

Nordi, N., Nishida, A. K., and Alves, R. R.: Effectiveness of two gathering techniques for Ucides cordatus in Northeast Brazil: im- 
plications for the sustainability of mangrove ecosystems, Hum. Ecol., 37, 121-127, https://doi.org/10.1007/s10745-009-9214-9, 2009.

Patterson, R. T. and Fishbein, E.: Re-examination of the statistical methods used to determine the number of point counts needed for micropaleontological quantitative research, J. Paleontol., 63, 245-248, 1989.

Paerl, H., Valdes, L., Peierls, B., Adolf, J., and Harding, L.: Anthropogenic and climate influences on the eutrophication of large estuarine ecosystems, Limnol. Oceanogr., 51, 448-462, https://doi.org/10.4319/lo.2006.51.1_part_2.0448, 2006.

Paludo, D. and Klonowski, V. S.: Barra de Mamanguape e PB: Estudo do impacto do uso de madeira de manguezal pela população extrativista e da possibilidade de reflorestamento e manejo dos recursos madeireiros, Conselho Nacional da Reserva da Biosfera da Mata Atlantica, Sao Paulo, 1999.

Passos, C., Kukimodo, I., and Semensatto Junior, D.: Foraminiferal assemblages along the intertidal zone of Itapanhaú River, Bertioga (Brazil), J. S. Am. Earth Sci., 79, 297-306, https://doi.org/10.1016/j.jsames.2017.08.017, 2017.

Rafaela, M., Filho, J., Rocha-Barreira, C., Matthews-Cascon, H., Santos, E., David, H., and Matos, A.: Benthic Estuarine Assemblages of the Northeastern Brazil Marine Ecoregion: A Benthic Perspective, in: Brazilian Estuaries, edited by: Lana, P. da C. and Bernardino, A. F., Springer, Berlin, Heidelberg, Germany, 75-94, https://doi.org/10.1007/978-3-319-77779-5_3, 2018.

Rickard, D.: How long does it take a pyrite framboid to form?, Earth Planet. Sc. Lett., 513, 64-68, https://doi.org/10.1016/j.epsl.2019.02.019, 2019.

Rouvillois, A.: Comparaison entre la faune de foraminifères de la surface des mangroves actuelles du Senégal de Bassid (Sine Saloum), d'Oussouye et de Balingor (Casamance) et celle d'un sondage à Bango (Delta du Fleuve Sénégal), Cah. Micropal., 2, 149-154, 1982.

Santos, E., Araújo, L., and Marcelino, A.: Análise climática da Bacia Hidrográfica do Rio Mamanguape, Rev. Brasil. Engen. Agrí. Amb., 19, 9-14, https://doi.org/10.1590/18071929/agriambi.v19n1p9-14, 2015.

Saunders, J. B.: Recent foraminifera of mangrove swamps and river estuaries and their fossil counterparts in Trinidad, Micropaleontology, 4, 79-92, 1958.

Scavia, D., Field, J., Boesch, D., Buddemeier, R., Burkett, V., Cayan, D., Fogarty, M., Harwell, M., Howarth, R., Mason, C., Reed, D., Royer, T., Sallenger, A., and Titus, J.: Climate Change Impacts on U.S. Coastal and Marine Ecosystems, Estuar. Coast., 25, 149-164, https://doi.org/10.1007/BF02691304, 2002.

Schiedek, D., Sundelin, B., Readman, J., and Macdonald, R.: Interactions between climate change and contaminants, Marine Pollution Bulletin, 54, 1845-1856, https://doi.org/10.1016/j.marpolbul.2007.09.020, 2008.

Scott, D. and Medioli, F.: Vertical zonations of marsh foraminifera as accurate indicators of former sea-levels, Nature, 272, 528531, https://doi.org/10.1038/272528a0, 1978.

Scott, D. B., Schnack, E. J., Espinosa, L., and Barbosa, C. F.: Recent Marsh Foraminifera from the East Coast of South America: Comparison to the Northern Hemisphere, Paleoecology, Biostratigraphy, Paleoceanography and Taxonomy of Agglutinated Foraminifera, 717-737, Kluwer Academic Publishers, Dordrecht, the Netherlands, 1990.
Semensatto Jr., D. L., Funo, R. H. F., Dias-Brito, D., and Coelho Jr., C.: Foraminiferal ecological zonation along a Brazilian mangrove transect: Diversity, morphotypes and the influence of subaerial exposure time, Rev. Micropaléontol., 52, 67-74, https://doi.org/10.1016/j.revmic.2008.06.004, 2009.

Shaw, T. A., Kirby, J. R., Holgate, S., Tutman, P., and Plater, A. J.: Contemporary salt-marsh foraminiferal distribution from the adriatic coast of croatia and its potential for sea-level studies, J. Foramin. Res., 46, 314-332, https://doi.org/10.2113/gsjfr.46.3.314, 2016.

Spalding, M., Fox, H., Allen, G., Davidson, N., Ferdaña, Z., Finlayson, M., Halpern, B., Jorge, M., Lombana, A. Lourie, S., Martin, K., McManus, E., Molnar, J., Recchia, C., and Robertson, J.: Marine Ecoregions of the World: A Bioregionalization of Coastal and Shelf Areas, BioScience, 57, 573-583, https://doi.org/10.1641/B570707, 2007.

Thiel, J., Byrne, J. M, Kappler, A., Schink, S., and Pester, M.: Pyrite formation from $\mathrm{FeS}$ and $\mathrm{H}_{2} \mathrm{~S}$ is mediated through microbial redox activity, P. Natl. Acad. Sci. USA, 116, 6897-6902, https://doi.org/10.1073/pnas.1814412116, 2019.

Thissen, J. M. and Langer, M. R.: Spatial Patterns and Structural Composition of Foraminiferal Assemblages from the Zanzibar Archipelago (Tanzania), Paleontographica, Abt. A: Palaeozoology - Stratigraphy, 308, 1-67, 2017.

Thomas, E. and Varekamp J. C.: Palaeo-environmental analyses of marsh sequences (Clinton, Connecticut): evidence for puncutated rise in relative sea level during the latest Holocene, J. Coast. Res., 11, Spec. Iss., 125-158, 1991.

Todd, R. and Brönnimann, P.: Recent foraminifera and thecamoebina from the eastern Gulf of Paria, Trinidad, Cushman Foundation for Foraminiferal Research, 3, 1-43, 1957.

Van der Linden, P., Marchini, A., Smith, C., Dolbeth, M., Simone, L., Marques, J., Joseline, M., Medeiros, C., and Patrício, J.: Functional changes in polychaete and mollusc communities in two tropical estuaries, Estuar. Coast. Shelf S., 187, 62-73, https://doi.org/10.1016/j.ecss.2016.12.019, 2017.

Weinmann, A. E.: Benthic shallow-water foraminifera from Fernando de Norohnha and Abrolhos, Brazil: A comparative study between two archipelagos and biogeographic analysis of larger foraminifera within the tropical western Atlantic Ocean, Master thesis, University of Bonn, 172 pp., 2009.

Wilson, B., Miller, K., Thomas, A. L., Cooke, N., and Ramsingh, R.: Foraminifera in the Mangal at the Caroni Swamp, Trinidad: Diversity, Population Structure and Relation to Sea Level, J. Foramin. Res., 38, 127-136, 2008.

Woodroffe, S. A., Horton, B. P., and Larcombe, P.: Contemporary intertidal foraminifera distributions of Cleveland Bay, Central Great Barrier Reef shelf, Australia: implications for sea-level reconstructions, J. Foramin. Res., 35, 259-270, 2005.

Zaninetti, L., Brönnimann, P., Dias-Brito, D. A., Mitsuru Casaletti, P., Koutsoukos, E., and Silveira, S.: Distribution écologique des Foraminifères dans la Mangrove d'Acupe, Etat de Bahia, Brésil, Notes du Laboratoire de Paleontologie de l'Université de Geneve, 4, 1-17, 1979. 